\title{
Systematic Reviews and Meta-Analysis
}

\section{Waiting times for prostate cancer: A review}

\author{
Giacomo Lazzeri, ${ }^{1,2}$ Gianmarco Troiano, ${ }^{3}$ Barbara Rita Porchia, ${ }^{2}$ Federica Centauri, ${ }^{2}$ \\ Vincenzo Mezzatesta, ${ }^{2}$ Giorgio Presicce, ${ }^{2}$ Daniela Matarrese, ${ }^{4}$ Roberto Gusinu ${ }^{5}$
}

\author{
${ }^{1}$ Department of Molecular and Developmental Medicine, University of Siena \\ ${ }^{2}$ Hospital Direction, Azienda Ospedaliera Universitaria Senese \\ ${ }^{3}$ University of Siena \\ ${ }^{4}$ Director of the Hospital Network, Azienda USL Toscana Centro \\ ${ }^{5}$ Medical Chief Director, Azienda Ospedaliera Universitaria Senese, Italy
}

\begin{abstract}
Prostate cancer is one of the most common diagnosed cancers in men and the waiting time has become an important issue not only for clinical reasons, but also mostly for the psychological implications on patients. The aim of our study was to review and analyze the literature on waiting times for prostate cancer. In February-March 2019 we performed a search for original peerreviewed papers in the electronic database PubMed (MEDLINE). The key search terms were "prostate cancer AND waiting list", "prostate cancer AND waiting times". We included in our narrative review articles in Italian, English or French, published in 2009-2019 containing original data about the waiting times for prostate cancer. The literature search yielded 680 publications. Finally, we identified 8 manuscripts eligible for the review. The articles were published between 2010 and 2019; the studies involved a minimum of 16 to a maximum of 95438 participants. Studies have been conducted in 6 countries. The waiting times from cancer suspicion to histopathological diagnosis and to treatment had an important reduction in the last years, and this constant decrease could lead to an increase of patients' satisfaction.
\end{abstract}

\section{Introduction}

Prostate cancer is the second most common diagnosed cancer in men, after the lung cancer. ${ }^{1}$ In the last years the number of men who received a diagnosis of prostate cancer has increased: the most important reason of this increase is the longer life expectancy. ${ }^{2}$ In fact, the risk of developing prostate cancer increases with age, and it is very rare in men younger than 50 years old. ${ }^{3}$ Surely the second most important reason is the introduction and diffusion of prostate-specific antigen (PSA) screening that led to a major number of prostate tumors diagnosis, in particular those at the initial stage, compared to the advanced ones. ${ }^{2,4}$ The advent of PSA testing and subsequent biopsy, led to an extraordinary change of the epidemiology of this tumor: now, up to $80 \%$ of diagnosed prostate cancer are at an initial stage, posing small risk of morbidity or mortality during patients' lifetime. ${ }^{5,6}$ Moreover, as reported in a recently published review, advances in the diagnosis and treatment of prostate cancer have improved the ability to stratify patients by risk and allowed clinicians to recommend therapy based on cancer prognosis and patient preference. ${ }^{7}$

On the basis of several definitions in the literature, the WHO definition of quality of care is "the extent to which health care services provided to individuals and patient populations improve desired health outcomes. In order to achieve this, health care must be safe, effective, timely, efficient, equitable and peoplecentred". 8,9

Patient satisfaction is an important measure of healthcare quality and is correlated with important outcomes, such as superior compliance, decreased utilization of medical services, less malpractice litigation and better prognosis. ${ }^{10}$

Waiting times are important for patient satisfaction and, in many jurisdictions, the improvement in their reduction (especially for cancer diagnosis and treatment) has become a priority. ${ }^{11}$ For example, the Swedish Government had initiated a project to reduce these waiting times by introducing national standardized clinical pathways. ${ }^{12}$ Similarly, England and Wales started the so called 'two weeks wait' programme, whilst in Denmark appeared the national cancer pathways. ${ }^{13,14}$ Waiting times are relevant not only for clinical reasons, but mostly for the psychological implications on patients: several studies conducted on other types of cancer, in fact, have analyzed the relation between perceived waiting times and patient satisfaction, although most of them focused only on parts of the perceived waiting time, namely, family physician referral to specialist visit ${ }^{15}$ and diagnosis to treatment. ${ }^{16}$

In literature there are several reported experiences about how long patients with suspected prostate cancer have to wait to receive a biopsy or treatment, so the aim of our narrative review was to analyze the studies published on this topic in order to have an overview.

Significance for public health

The improvement in the reduction of the so-called "Waiting Times" for diagnosis and treatment of cancer has become a priority for several countries. In fact, the "Waiting times" are relevant not only for clinical reasons, but mostly for the psychological implications on patients and for their satisfaction, which is recognized as a key indicator of healthcare quality. Our narrative review focused on the waiting times for prostate cancer that is one of the most common diagnosed cancers in men. 


\section{Methods}

In February-March 2019 we performed a search for original peer-reviewed papers in the electronic database PubMed (MEDLINE). The key search terms were "prostate cancer AND waiting list", "prostate cancer AND waiting times". The inclusion criteria that we chose for our narrative review were: i) type of article (original articles, but also letters to the editor or short communications if containing original data); ii) date of publication between 2009 and 2019; iii)language (Italian, English or French); iv) availability of information about country, study period, source of the data, number of participants, waiting times. Other interesting data have also been reported.

Studies were selected in a 3-stage process. First we analyzed the titles; then the abstracts from electronic searches. Finally we collected and read the full manuscripts to select the eligible manuscripts according to the inclusion criteria

\section{Results}

The literature search yielded 680 publications. The titles of these manuscripts were screened, resulting in 12 studies considered potentially eligible for abstract analysis (18 were duplicate, 76 were review, 249 were published before 2009, 312 were not in line with the aim of our study, 13 were in other languages - 1 Chinese, 4 German, 5 Spanish, 1 Dutch, 1 Norwegian, 1 Hungarian).

After abstract analysis 2 studies were further excluded because not in line with the aim of our study, so the full texts analysis was conducted on 10 manuscripts. Finally, after this exclusion we identified 8 manuscripts eligible for the review (2 excluded because not in line with the aim of the study) (Figure 1). ${ }^{11,12,17-22}$

The articles were published between 2010 and 2019; the studies have been conducted from 1996 to 2015; they involved a minimum of 16 to a maximum of 95438 participants. Studies have been conducted in Poland, Canada, Sweden, South Africa, United Kingdom (UK) and France.

The principal results of our review are shown in Table 1.

In some examined studies the waiting time for prostate cancer has been divided in subgroups: from cancer suspicion to histopathological confirmation, and from cancer diagnosis to the start of treatment; other studies described the total waiting time from cancer suspicion to treatment.

\section{Waiting time from cancer suspicion to treatment}

Two studies reported this datum: ${ }^{17,22}$ although settled in different countries we observed (after almost 10 years) a clear reduction of this time from 247 days to 18.7 weeks (almost 130 days).

\section{Waiting time from cancer suspicion to histopathological confirmation}

Four studies reported this datum: ${ }^{11,17,21,22}$ we observed a substantial stable trend during the years of this 'time' (53 days in 2003; 7.7 weeks in 2014-15). The results described by Singh and by Mathews are not totally comparable.

\section{Waiting time from cancer diagnosis to the start of treatment}

Seven studies reported this datum: ${ }^{12,17-22}$ also for this datum we observed a net reduction of this 'time' from almost 1200-1400 days (referred to chemotherapy) or 200 days (referred to surgery or radiotherapy) in 2002 to 8.7 weeks in 2015 (almost 60 days).

\section{Other findings}

Two authors reported that high-risk patients had shorter waiting times; one author ${ }^{17}$ reported a significantly higher waiting time for patients who underwent radiotherapy, however this time has diminished in the years as reported by Rastpour et al. ${ }^{19}$

One author observed no differences in survival on the basis of the time of surgery (immediate, or after 4-6 months). ${ }^{20}$

\section{Discussion}

The topic of "waiting times" has been investigated for several cancers. Already in 2017, Labbè et al. focused on lung cancer that is the most frequently diagnosed cancer worldwide and the leading cause of cancer-related mortality. In their study they affirmed that reducing wait times should be a goal, because shorter waits might influence important variables such as quality of life, cost of care, access to therapies. ${ }^{23}$

Our study was focused on waiting times for prostate cancer and the analysis of the literature highlighted a reduction of these times during the years. However, as reported by Robertson et al., men with prostate cancer had substantially longer waiting times than patients with other kinds of cancer. ${ }^{12}$

Some limitations should be considered: first of all, our review was not systematic, but it could be considered a narrative review conducted on a single database. Moreover, the literature is limited to some countries (specifically six countries), so it is difficult to have a complete overview of this topic able to represent the worldwide situation. Substantial differences among countries are actually impossible to define.

Another weakness of our study is the not-total comparability of the data retrieved by the analyzed articles.

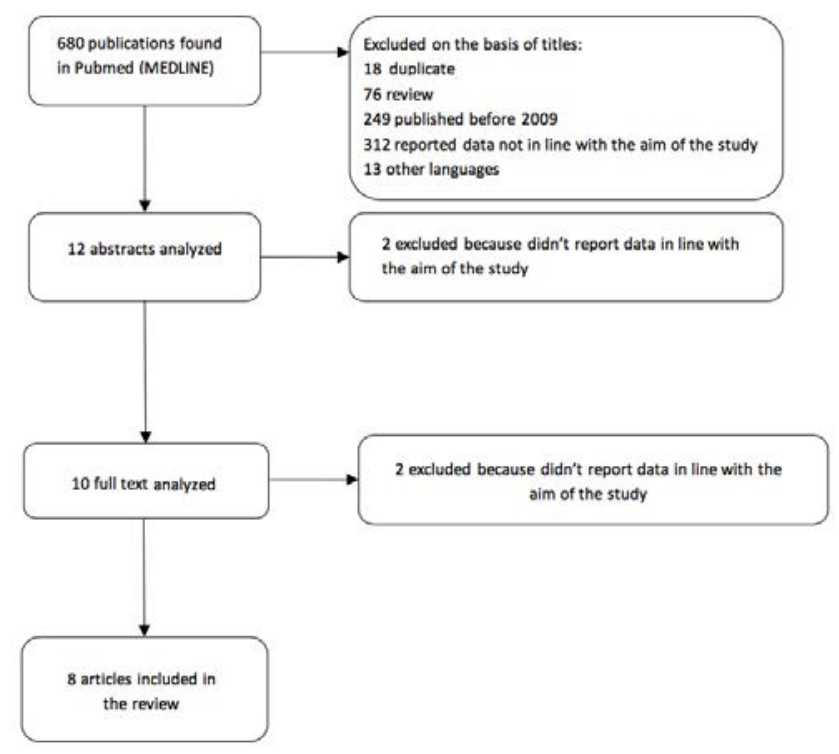

Figure 1. Flow diagram for identifying studies included in our non-systematic (narrative) review. 
Systematic Reviews and Meta-Analysis

Table 1. Selected characteristics of the studies included in the review.

\begin{tabular}{|c|c|c|c|c|c|c|c|}
\hline $\begin{array}{l}\text { Author, Country } \\
\text { year }\end{array}$ & $\begin{array}{l}\text { Study } \\
\text { period }\end{array}$ & $\begin{array}{l}\text { Involved } \\
\text { centers }\end{array}$ & $\begin{array}{l}\text { Data } \\
\text { source }\end{array}$ & Participants & $\begin{array}{l}\text { Age } \\
\text { (years) }\end{array}$ & $\begin{array}{l}\text { Waiting time } \\
\text { from cancer } \\
\text { suspicion to } \\
\text { treatment }\end{array}$ & $\begin{array}{l}\text { Waiting time } \\
\text { from cancer } \\
\text { suspicion to } \\
\text { histopathological } \\
\text { confirmation }\end{array}$ \\
\hline $\begin{array}{l}\text { Osowiecka, Poland } \\
2019^{17}\end{array}$ & $2014-2015$ & 5 & Questionnaire & 123 & $\begin{array}{l}\text { - median } 65 \\
\text { - range 53-87 }\end{array}$ & $\begin{array}{l}18.7 \text { weeks (IQR } \\
10.6-26.9 \text { weeks) }\end{array}$ & $\begin{array}{l}7.7 \text { weeks (IQR } \\
4.0-16.1 \text { weeks) }\end{array}$ \\
\hline
\end{tabular}

treatment

4.6-14.1 weeks
A significant longer

waiting time for

patients who began

treatment with radiation

therapy $(\mathrm{p}<0.001)$

\begin{tabular}{|c|c|c|c|c|c|c|c|c|c|c|}
\hline $\begin{array}{l}\text { Rastpour, } \\
\text { 2018 }\end{array}$ & Canada & 2002-2012 & $n / r$ & $\begin{array}{c}\text { Retrospective } \\
\text { administrative } \\
\text { data }\end{array}$ & 95438 & $n / r$ & $n / r$ & $n / r$ & $\begin{array}{l}\text { From diagnosis to } \\
\text { chemotherapy 1200/1400 } \\
\text { days (in 2002) - } \\
400 \text { days (in 2012) } \\
\text { From diagnosis to } \\
\text { radiotherapy or } \\
\text { surgery almost } 200 \text { days }\end{array}$ & $\begin{array}{l}\text { - Increasing trend in } \\
\text { median waiting time per } \\
\text { year for surgery } \\
\text { (2.6 days) } \\
\text { - Decreasing trend } \\
\text { in median waiting } \\
\text { time per year for } \\
\text { radiotherapy (-2.8 days) } \\
\text { - Decreasing trend in } \\
\text { median waiting time per } \\
\text { year for chemotherapy } \\
\text { (-84.0 days) }\end{array}$ \\
\hline $\begin{array}{l}\text { Robertson, } \\
2017^{12}\end{array}$ & Sweden & 2013 & $n / r$ & $\begin{array}{l}\text { Data furnished } \\
\text { by National Board } \\
\text { of Health } \\
\text { and Welfare }\end{array}$ & 1955 & $n / r$ & $n / r$ & $n / r$ & 172 days & $\begin{array}{l}\text { The median wating time } \\
\text { for men with } \\
\text { high-risk prostate } \\
\text { cancer was } 26 \text { days } \\
\text { shorter than for men } \\
\text { with intermediate-risk } \\
\text { prostate cancer }\end{array}$ \\
\hline $\begin{array}{l}\text { Singh, } \\
2015^{21}\end{array}$ & $\begin{array}{l}\text { South } \\
\text { Africa }\end{array}$ & 2013 & 1 & $\begin{array}{l}\text { Retrospective } \\
\text { folder review }\end{array}$ & $\begin{array}{c}106 \\
(52 \text { had } \\
\text { confirmed } \\
\text { adenocarcinoma) }\end{array}$ & $\begin{array}{l}\text { - mean } \\
67.6 \text { years } \\
\text { - standard } \\
\text { deviation } 7.51\end{array}$ & & $\begin{array}{l}100 \text { days**** } \\
\left({ }^{* * * *} \text { number of days }\right. \\
\text { a patient waited to receive } \\
\text { a histological diagnosis, } \\
\text { and for treatment } \\
\text { options to be discussed } \\
\text { or instituted) }\end{array}$ & 100 days $* * * *$ & $\begin{array}{l}\text { - Median period to receive } \\
\text { biopsy after suspicion: } \\
55 \text { days } \\
\text { - Median period of histological } \\
\text { processing time: } 36 \text { days }\end{array}$ \\
\hline $\begin{array}{l}\text { Mathews, } \\
2015^{11}\end{array}$ & Canada & $n / r$ & $n / \mathrm{r}$ & $\begin{array}{l}\text { Interviews } \\
\text { (conducted either } \\
\text { in-person } \\
\text { or by phone) }\end{array}$ & 16 & $\begin{array}{l}-<65 \text { years }(50 \%) \\
->65 \text { years old }(50 \%)\end{array}$ & $n / r$ & $\begin{array}{l}\text { 84.0 days (range } 5-642)^{* *} \\
\left({ }^{* *} \text { authors refer to }\right. \\
\text { the time from the first } \\
\text { visit to diagnosis) }\end{array}$ & $n / r$ & $n / r$ \\
\hline $\begin{array}{l}\text { Redaniel, } \\
2013^{20}\end{array}$ & UK & $1996-2009$ & $n / r$ & $\begin{array}{c}\text { Dataset } \\
\text { furnished by } \\
\text { South West Public } \\
\text { Health } \\
\text { Observatory } \\
\text { (SWPHO) }\end{array}$ & 17043 & $\begin{array}{l}-15-54 \text { years }(11.68 \%) \text {. } \\
-55-64 \text { years }(51.86 \%) \\
->65 \text { years }(36.46 \%)\end{array}$ & $\mathrm{n} / \mathrm{r}$ & $n / r$ & $\begin{array}{l}95 \text { days } \\
\text { (IQR 70-125 days) }\end{array}$ & $\begin{array}{l}\text { No differences were } \\
\text { observed in the survival } \\
\text { among patients who } \\
\text { underwent surgery at } \\
\text { time } 0-3 \text { and at time } \\
4-6 \text { months }\end{array}$ \\
\hline $\begin{array}{l}\text { Pourcel, } \\
2013^{18}\end{array}$ & France & 2012 & $\mathrm{n} / \mathrm{r}$ & Medical records & 4207 & $\begin{array}{l}\text { - Mean 68.0 years } \\
\text {-SD } 8.8\end{array}$ & $n / r$ & $n / r$ & $\begin{array}{l}\text { - Mean } 36.5 \text { days (SD 26.5) } \\
\text { from pathologist } \\
\text { diagnosis to treatment } \\
\text { proposal } \\
\text { - Mean } 45.2 \text { days } \\
\text { (SD } 30.1 \text { or 38) from } \\
\text { proposal to the start } \\
\text { of treatment (non surgical } \\
\text { or surgical) }\end{array}$ & $n / r$ \\
\hline $\begin{array}{l}\text { Stevens, } \\
2010^{22}\end{array}$ & Canada & 2003 & 1 & $\begin{array}{l}\text { Semi-structured } \\
\text { interview }\end{array}$ & 41 & $\begin{array}{l}\text { - median } 70 \\
\text { - range } 41-77\end{array}$ & $\begin{array}{l}247 \text { days }{ }^{*} \\
\text { ( }{ }^{\text {from }} \\
\text { suspicion to the } \\
\text { first fraction) } \\
\text { of RT }\end{array}$ & $\begin{array}{l}53 \text { days } \\
\text { (Sub-intervals: } \\
\text { - from suspicion to } \\
\text { consultation with } \\
\text { an urologist = } 40 \text { days } \\
\text { - from consultation to } \\
\text { biopsy = } 26 \text { days) }\end{array}$ & $\begin{array}{l}127 \text { days*** } \\
\text { (***from biopsy to first } \\
\text { fraction of RT) }\end{array}$ & $\begin{array}{l}\text { From diagnosis to start of RT, } \\
\text { intermediate and } \\
\text { high-risk patients } \\
\text { had shorter wait } \\
\text { times compared to } \\
\text { low-risk patients } \\
(124 \text { ss. } 178 \text { days; } p=0.041) \\
70 \% \text { of participants perceived a } \\
\text { delay in their prostate cancer } \\
\text { pathway }\end{array}$ \\
\hline
\end{tabular}

IQR, interguartile range; RT, radiotherapy, n/, not reported; SD, standard deviation.
Sub-intervals.

com suspicion to

n urologist $=40$ days

from consultation to

biopsy $=26$ days $)$ 
As for the "waiting times from cancer suspicion to treatment", although we observed a clear reduction of this time during the years, it should be specified that Stevens et al. in their article specifically refer to radiotherapy, whilst Osowiecka et al. generically refer to all the available treatments.

As for the "waiting times from cancer suspicion to histopathological confirmation" the only studies that reported comparable data are those of Osowiecka and Stevens: in fact the results described by Singh and by Mathews are quite different. In particular, Singh reported the number of days that a patient waited to receive a histological diagnosis, and for treatment options to be discussed or instituted; Mathews, instead, reported the time from the first visit to diagnosis, but it is not clear if this visit is from a general practitioner or a specialized doctor.

As for the "waiting time from cancer diagnosis to the start of treatment", Osowiecka, Robertson, and Redaniel, Singh did not specify the type of treatment; whilst Pourcel and Stevens focused on surgical/non surgical treatment and on radiotherapy respectively. Stevens et al. reported an interesting datum regarding patients perception of waiting times: in their study $70 \%$ of participants perceived their "waiting time" as a delay in their prostate cancer pathway.

Surely, as demonstrated in studies conducted on colorectal cancer, shorter waiting times are correlated with higher levels of patients' satisfaction; ${ }^{24}$ however, in many cases, patients with longer waiting times generally had less advanced disease and better survival, so the typical delays are not of clinical significance. ${ }^{25}$ Wanis et al. confirmed these evidences reporting that, despite longer median colon cancer treatment waiting times from diagnosis to surgery (exceeding 30 days or 2-3 months), no adverse impact on survival has been observed. ${ }^{26}$

In our study, Redaniel et al. confirmed these evidences for prostate cancer observing no differences in the survival among patients who underwent surgery at time $0-3$ and at time 4-6 months. In fact, among men with low-risk prostate carcinoma, a treatment delay of several months does not appear to compromise long-term oncologic results following definitive treatment. ${ }^{27}$ Also considering only radiotherapy as treatment, the delay does not affect outcomes in low-risk patients. ${ }^{28}$

The only reported side effect is that treatment delay between biopsy and prostatectomy in patients with a high risk may result in more extensive periprostatic tissue resection and may adversely affect postoperative continence and erectile function. ${ }^{29}$

\section{Conclusions}

Concluding, prostate cancer is one of the life threatening and most frequent case of disorders and a proper treatment and other control strategies are fundamental to manage it. ${ }^{30}$ Our review, although with some limitations due to the choice to use only one biomedical database, demonstrated that the "Waiting time from cancer suspicion to treatment", the "Waiting time from cancer suspicion to histopathological confirmation" and the "Waiting time from cancer diagnosis to the start of treatment" are constantly diminishing. Although not of clinical significance, this reduction could be positively felt by patients, and could lead to an increase of patients satisfaction, recognized as a key indicator of health care quality, especially in oncology. ${ }^{31}$ Since a recent study has found a negative association between diagnostic delay and patient satisfaction in gynecologic cancer patients, ${ }^{32}$ it is therefore conceivable that, also for prostate cancer, a delay and a longer waiting time could lead to a lower satisfaction level.
Correspondence: Gianmarco Troiano, Department of Molecular and Developmental Medicine, University of Siena, 2 Via A. Moro, 53100 Siena, Italy.

E-mail: gianmarco.troiano@student.unisi.it or gianmarco-89@hotmail.it

Key words: Prostate cancer; waiting time; review.

Contributions: GL, GT, RG are the primary authors of this article; FC, VM, GP, BP, DM served as a project coinvestigators and contributed substantially to the development of the manuscript. All authors have read and approved the manuscript and agreed to be accountable for all aspects of the work.

Conflict of interest: The authors declare no competing interest.

Funding: No one received for this study.

Received for publication: 27 April 2020.

Accepted for publication: 26 May 2020.

oCopyright: the Author(s), 2020

Licensee PAGEPress, Italy

Journal of Public Health Research 2020;9:1778

doi:10.4081/jphr.2020.1778

This work is licensed under a Creative Commons Attribution NonCommercial 4.0 License (CC BY-NC 4.0).

\section{References}

1. Merriel SWD, Funston G, Hamilton W. Prostate cancer in primary care. Adv Ther 2018;35:1285-94.

2. Stangelberger A, Waldert M, Djavan B. Prostate cancer in elderly men. Rev Urol 2008;10:111-9.

3. InformedHealth.org [Internet]. Cologne, Germany: Institute for Quality and Efficiency in Health Care (IQWiG); 2006. Prostate cancer: Overview. [Access date 4 Apr 2019]. Available from: https://www.ncbi.nlm.nih.gov/books/NBK284 958/

4. Caldarelli G, Troiano G, Rosadini D, Nante N. Can PSA Reflex Algorithm be a valid alternative to other PSA-based prostate cancer screening strategies? Ann Ig 2017;29:218-22.

5. Albertsen PC, Hanley JA, Fine J. 20-year outcomes following conservative management of clinically localized prostate cancer. JAMA 2005;293:2095-101.

6. Cooperberg MR, Broering JM, Carroll PR. Time trends and local variation in primary treatment of localized prostate cancer. J Clin Oncol 2010;28:1117-23.

7. Litwin MS, Tan HJ. The diagnosis and treatment of prostate cancer: A review. JAMA 2017;317:2532-42.

8. WHO. What is quality of care and why is it important? 2020. Available from: https://www.who.int/maternal_child_adolescent/topics/quality-of-care/definition/en/.

9. Lazzeri G, Centauri F, Mezzatesta V, et al. Accreditation and quality in the Italian National Health Care System: a 10 years long review. EBPH 2019;16:e13103-1/8.

10. Huang JA, Lai CS, Tsai WC, et al. Determining factors of patient satisfaction for frequent users of emergency services in a medical center. J Chin Med Assoc 2004;67:403-10.

11. Mathews M, Ryan D, Bulman D. What does satisfaction with wait times mean to cancer patients? BMC Cancer 2015;15:1017.

12. Robertson S, Adolfsson J, Stattin P, et al. Waiting times for 
cancer patients in Sweden: A nationwide population-based study. Scand J Public Health 2017;45:230-7.

13. Health \& Social Care Information Centre, NHS England. Cancer waiting times: A guide (version 9.0). Accessed on: 8 November 2015. Available from: http://www.swscn. org.uk/wp/wp-content/uploads/2018/11/Cancer-WaitingTimes-Guidance-v9.pdf

14. Danish Health and Medicines Authority. Cancer pathways. Accessed on: 0 December 2014. Available from: http://sundhedsstyrelsen.dk/en/health/widespread-diseases/cancer/cancer-pathways

15. Thind A, Stewart M, Manuel D, et al. What are wait times to see a specialist? An analysis of 26,942 referrals in southwestern Ontario. Healthcare Policy 2012;8:80-91.

16. Mackillop WJ, Fu H, Quirt C, et al. Waiting for radiotherapy in Ontario. Int J Radiat Oncol Biol Phys 1994;30:221-8.

17. Osowiecka K, Nawrocki S, Kurowicki M, Rucinska M. The waiting time of prostate cancer patients in Poland. Int J Environ Res Public Health 2019;16:342.

18. Pourcel G, Ledesert B, Bousquet PJ, et al. [Waiting times for cancer care in four most frequent cancers in several French regions in 2011 and 2012].[Article in French]. Bull Cancer 2013;100:1237-50.

19. Rastpour A, Begen MA, Louie AV, Zaric GS. Variability of waiting times for the 4 most prevalent cancer types in Ontario: a retrospective population-based analysis. CMAJ Open 2018;6:E227-34.

20. Redaniel MT, Martin RM, Gillatt D, et al. Time from diagnosis to surgery and prostate cancer survival: a retrospective cohort study. BMC Cancer 2013;13:559.

21. Singh K, Abdel Goad EH, Ramklass SS. Waiting times for prostate cancer diagnosis in KwaZulu-Natal, South Africa. S Afr Med J 2015;105:484-6.

22. Stevens C, Bondy SJ, Loblaw DA. Wait times in prostate can- cer diagnosis and radiation treatment. Can Urol Assoc J 2010;4:243-8.

23. Labbe C, Anderson M, Simard S, et al. Wait times for diagnosis and treatment of lung cancer: a single-centre experience. Curr Oncol 2017;24:367-73.

24. Singh H, De Coster C, Shu E, et al. Wait times from presentation to treatment for colorectal cancer: a population-based study. Can J Gastroenterol 2010;24:33-9.

25. Comber H, Cronin DP, Deady S, et al. Delays in treatment in the cancer services: impact on cancer stage and survival. Irish Med J 2005;98:238-9.

26. 2Wanis KN, Patel SVB, Brackstone M. Do moderate surgical treatment delays influence survival in colon cancer? Dis Colon Rectum 2017;60:1241-9.

27. van den Bergh RC, Albertsen PC, Bangma CH, et al. Timing of curative treatment for prostate cancer: a systematic review. Eur Urol 2013;64:204-15.

28. Nguyen PL, Whittington R, Koo S, et al. The impact of a delay in initiating radiation therapy on prostate-specific antigen outcome for patients with clinically localized prostate carcinoma. Cancer 2005;103:2053-9.

29. Sun M, Abdollah F, Hansen J, et al. Is a treatment delay in radical prostatectomy safe in individuals with low-risk prostate cancer? J Sex Med 2012;9:2961-9.

30. Chen FZ, Zhao XK. Prostate cancer: current treatment and prevention strategies. Iran Red Crescent Med J 2013;15:279-84.

31. Pita-Fernandez S, Pertega-Diaz S, Lopez-Calvino B, et al. Diagnostic and treatment delay, quality of life and satisfaction with care in colorectal cancer patients: a study protocol. Health Qual Life Outcomes 2013;11:117.

32. Robinson KM, Christensen KB, Ottesen B, Krasnik A. Diagnostic delay, quality of life and patient satisfaction among women diagnosed with endometrial or ovarian cancer: a nationwide Danish study. Qual Life Res 2012;21:1519-25. 